OPEN ACCESS

Edited by:

Martyn Tranter,

University of Bristol, United Kingdom

Reviewed by:

Marek Stibal,

Charles University, Czechia

Christopher Williamson,

University of Bristol, United Kingdom

*Correspondence:

Nozomu Takeuchi

ntakeuch@faculty.chiba-u.jp

Specialty section:

This article was submitted to

Geochemistry,

a section of the journal

Frontiers in Earth Science

Received: 31 May 2018

Accepted: 11 January 2019

Published: 01 February 2019

Citation:

Takeuchi N, Tanaka S, Konno Y, Irvine-Fynn TDL, Rassner SME and

Edwards A (2019) Variations

in Phototroph Communities on

the Ablating Bare-Ice Surface

of Glaciers on Brøggerhalvøya, Svalbard. Front. Earth Sci. 7:4.

doi: 10.3389/feart.2019.00004

\section{Variations in Phototroph Communities on the Ablating Bare-Ice Surface of Glaciers on Brøggerhalvøya, Svalbard}

\author{
Nozomu Takeuchi1*, Sota Tanaka', Yudai Konno', Tristram D. L. Irvine-Fynn², \\ Sara M. E. Rassner ${ }^{2,3}$ and Arwyn Edwards ${ }^{3}$
}

${ }^{1}$ Department of Earth Sciences, Graduate School of Science, Chiba University, Chiba, Japan, ${ }^{2}$ Department of Geography and Earth Sciences, Aberystwyth University, Aberystwyth, United Kingdom, ${ }^{3}$ Institute of Biological, Rural and Environmental Sciences, Aberystwyth University, Aberystwyth, United Kingdom

During the summer ablation season, Arctic glacier surfaces host a wealth of microbial life. Here, the phototroph communities on the ablating bare-ice surface of three valley glaciers on Brøggerhalvøya, Svalbard were investigated. The communities mainly comprised seven taxa of green algae and cyanobacteria, which have been commonly reported on Arctic glaciers. Although the geographical and glaciological settings of the three studied glaciers are similar, there were differences in total phototroph biomass. The community structure was also distinctive among the glaciers: high dominance of a single taxon of green algae (Ancylonema nordenskiöldii) for Midtre Lovénbreen, abundant cyanobacteria for Austre Brøggerbreen, and diverse green algae for Pedersenbreen. The major soluble ions in the surface ice showed that there was no significant difference in meltwater nutrient conditions between the glaciers, but there were lower concentrations of mineral-derived ions on Midtre Lovénbreen. Consequently, the glacierspecific mineral loading and surface hydrology are inferred to explain the contrast in bare ice algal communities between the glaciers. We hypothesize that local, glacier-specific conditions affect algal communities and the associated influences on carbon cycling and ice-surface albedo.

Keywords: ice algae, Svalbard, glaciers, cyanobacteria, cryoconite

\section{INTRODUCTION}

Within the Earth system, glaciers and ice sheets are an important microbe-dominated ecosystem (Hodson et al., 2008), harboring an estimated $10^{29}$ microbes (Irvine-Fynn and Edwards, 2014). With microorganisms being able to thrive in any wet environment within a glacier, the seasonally melting surface is a prominent habitat (Stibal et al., 2012). During winter months, glaciers are typically snow-covered, but, characteristically, summer season snowmelt exposes the bare-ice in the ablation area, leaving snow cover only in the higher elevation accumulation area. Given the difference of physical and chemical properties of the snow and bare-ice, distinctive biological communities appear in these two environments (e.g., Yoshimura et al., 1997; Lutz et al., 2017). Yet, to date, data describing these habitat and species diversities remain limited, necessitating continued progress in the understanding of extant conditions (Hotaling et al., 2017). 
The supraglacial bare-ice area is usually inhabited by more abundant and diverse ranges of organisms compared with the accumulation area since the duration of surface melting is longer and liquid water is readily available at the ice surface (Yoshimura et al., 1997; Stibal et al., 2012). Ice algae and cyanobacteria are the prominent photosynthetic microbes in the ablation area (Anesio et al., 2009; Cook et al., 2012; Yallop et al., 2012; Williamson et al., 2018). The most common species of phototrophs on Arctic glaciers are Ancylonema nordenskiöldii and Mesotaenium bergrenii, which belong to desmids of green algae and are characterized by dark brownish pigments in their cells (Remias et al., 2012a,b; Takeuchi et al., 2015). Cyanobacteria are typically filamentous and often form spherical microbemineral aggregates, referred to as cryoconite granules (Langford et al., 2010; Cook et al., 2016a). Heterotrophs sustained by such photosynthetic microbes, are also present on the ice surface including rotifers, tardigrades, yeast, fungi and heterotrophic bacteria (Edwards et al., 2011, 2013; Cameron et al., 2012; Singh and Singh, 2012; Gokul et al., 2016; Zawierucha et al., 2015; Vonnahme et al., 2016).

The microbial activity across bare-ice is accentuated by the variety of habitats arising from the heterogeneous topography compared with that found in the accumulation area. Such topographic features include, for example, cryoconite holes, distributed dust and cryoconite, meltwater streams, and exposed bare-ice surfaces (Hodson et al., 2008). However, the bareice surface commonly accounts for more than $90 \%$ of the ice area (Hodson et al., 2007), and is inhabited by abundant phototrophs. Phototrophs on the bare-ice surface are thought to maintain higher rates of carbon fixation than the microbiota associated with cryoconite holes (Cook et al., 2012; Williamson et al., 2018). Furthermore, they play a role in accelerating ice ablation by the reduction of surface albedo (Yallop et al., 2012; Stibal et al., 2017; Ryan et al., 2018). Dark pigments contained in algal cells effectively absorb light, thereby reducing surface albedo (Remias et al., 2012b; Williamson et al., 2018). Moreover, the ablating bare-ice surface is not usually not continuous, solid, and homogenous. Rather, bare-ice is typically characterized by a variety of emergent structures and their associated orientations, ice types and crystal sizes (Hambrey and Lawson, 2000; Hudleston, 2015), and becomes porous during the summer season as a consequence of solar radiation penetrating through the ice and preferentially melting the ice crystal boundaries (Cook et al., 2016b). This porous ice, termed the weathering crust (Müller and Keeler, 1969), represents a photic zone (Irvine-Fynn and Edwards, 2014) which provides void space for microbes growing on the surface of ice crystals (Mader et al., 2006; Christner et al., 2018), and prevents them from being efficiently removed by supraglacial meltwater drainage (Irvine-Fynn et al., 2012). The microbial ecology related to the supraglacial weathering crust, its hydrology, and nutrient dynamics, is a key to understand biogeochemical significance of the bare-ice surface (Irvine-Fynn and Edwards, 2014; Christner et al., 2018; Stevens et al., 2018). However, there is still a dearth of information on the microbial communities living on the bareice surface compared with those reported for cryoconite holes specifically.
Svalbard is one of the more glaciated areas in the Arctic with ice covering $57 \%$ of the land area (Hagen et al., 1993; Nuth et al., 2013) and diverse microbe communities have been reported on the archipelago's glaciers (e.g., Säwström et al., 2002; Stibal et al., 2006; Edwards et al., 2011; Vonnahme et al., 2016). However, to date, most of the biological studies have focused on microbes in cryoconite holes that characterize these ice masses (e.g., Säwström et al., 2002; Stibal et al., 2006; Edwards et al., 2011; Vonnahme et al., 2016). Therefore, this study describes the phototroph community on the bare-ice surface of three neighboring glaciers on Brøggerhalvøya in Svalbard. The spatial variations in the algal community within and among glaciers are discussed with respect to factors associated with hydrology and nutrients on the ice surface.

\section{STUDY SITE AND METHODS}

The investigation was conducted in August 2013 on three north-facing Arctic valley glaciers south of Kongsfjord, Svalbard: Austre Brøggerbreen, Midtre Lovénbreen, and Pedersenbreen, which were all accessed from $\mathrm{Ny}$ Alesund $\left(78^{\circ} 55 \mathrm{~N}, 11^{\circ} 56 \mathrm{E}\right.$, Figures 1a-d). They are similar sized valley glaciers $\left(\sim 5 \mathrm{~km}^{2}\right)$, extending from elevations of $\sim 50-700 \mathrm{~m}$ a.s.l. (Hagen et al., 1993). All glaciers have shown recession from their Little Ice Age (LIA) maximum extents around a century ago (Nuth et al., 2013), and have velocities of less than $10 \mathrm{~m} \mathrm{a}^{-1}$ (Hagen et al., 1993; Rippin et al., 2005; Ai et al., 2014). Geophysical investigations have shown Austre Brøggerbreen to be coldbased with ice thicknesses $<100 \mathrm{~m}$, while Midtre Lovénbreen and Pedersenbreen are polythermal, with temperate ice in their thickest regions where ice depths reach up to around 170 m (see Björnsson et al., 1996; Ai et al., 2014). All glaciers have accumulation areas in Proterozoic basement rock types, principally mica schists, gneiss and migmatite (Hjelle, 1993). Their ablation zones are flanked by Proterozoic phyllite, and at the lowest ice elevations by Carboniferous sandstones and shales and some conglomerates (Hjelle, 1993). The snow line was located above $400 \mathrm{~m}$ a.s.l. when the field work was conducted, and the bare-ice area appeared to be close to its maximum at the time of study, as typically the air temperature at Ny Alesund is above $0^{\circ} \mathrm{C}$ from June to August (Svendsen et al., 2002).

Sample collections were carried out at three sites on Austre Brøggerbreen (AB1, 2, 3), two sites on Midtre Lovénbreen (ML1, 2), and two sites on Pedersenbreen (PD1, 2) (see Figure 1a). Sites were selected along the main central flow line of the glaciers, and across bare-ice elevation ranges from $120 \mathrm{~m}$ to $297 \mathrm{~m}$ a.s.l. and were considered representative of the broader bare-ice characteristics observed at each glacier. To analyze major soluble ions in local meltwater on the glaciers, five samples of meltwater were abstracted from cryoconite holes or small melt ponds found at each study site. Following standard methods, the meltwater was filtered through a $0.45 \mu \mathrm{m}$ ion-free disposable filter (Chromatodisk, GL-science, Japan) to remove particulate dust or microbes. The major ion concentrations in the samples, including $\mathrm{Na}^{+}, \mathrm{Cl}^{-}, \mathrm{K}^{+}, \mathrm{Ca}^{2+}$, $\mathrm{Mg}^{2+}, \mathrm{SO}_{4}{ }^{2-}, \mathrm{NH}_{4}{ }^{+}, \mathrm{NO}_{2}{ }^{-}, \mathrm{NO}_{3}{ }^{-}$, and $\mathrm{PO}_{4}{ }^{3-}$, were analyzed 

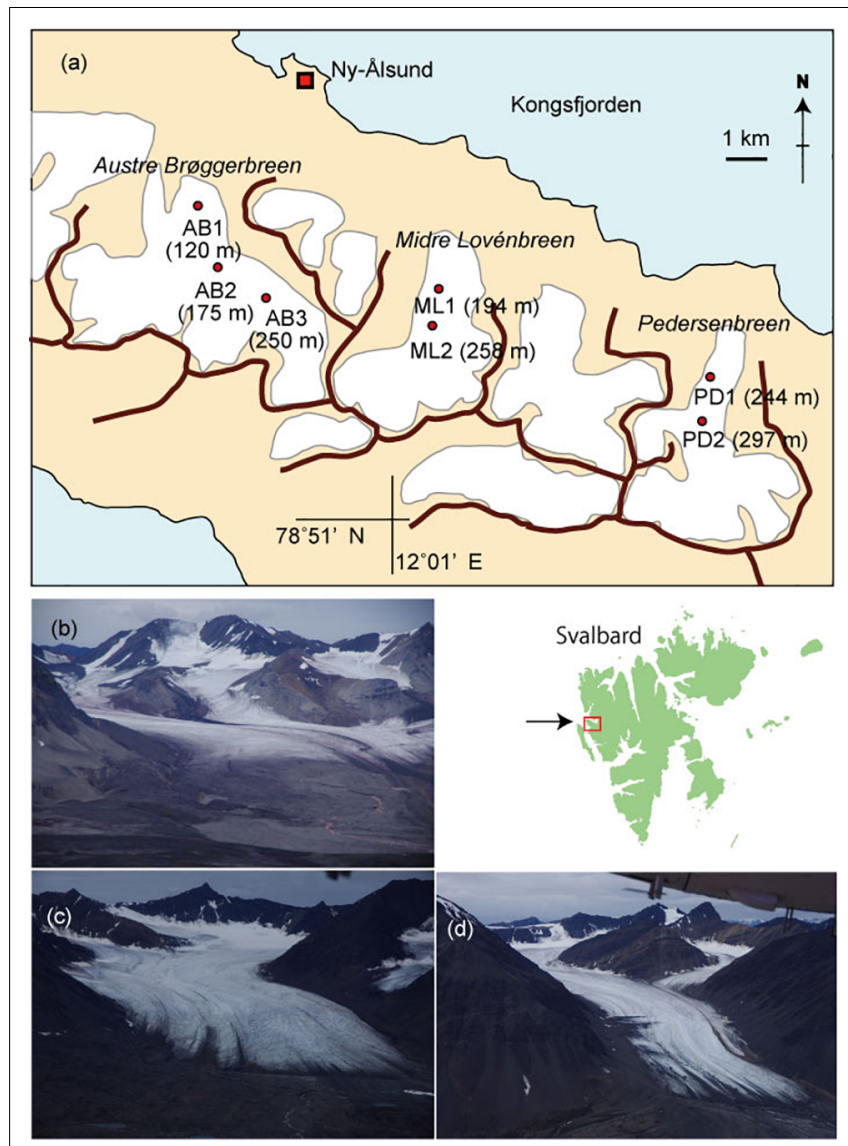

FIGURE 1 | A map of glaciers studied in Svalbard showing the sampling sites (a) and photographs of the glaciers. (b) Austre Brøggerbreen, (c) Midtre Lovénbreen, (d) Pedersenbreen.

with an ion-chromatography system (ICS-1100, Thermo Fisher Scientific), and concentrations given in equivalent units ( $\mu$ eq $\mathrm{L}^{-1}$ ). The measurement precision for all of the ionic species was approximately $10 \%$. In this study, $\mathrm{PO}_{4}{ }^{3-}$ and $\mathrm{NO}_{2}{ }^{-}$were below detection level at all of the samples. Non sea salt concentrations of each ion were obtained based on $\mathrm{Na}^{+}$values (after Holland, 1978).

To analyze phototroph community at each site, five samples of randomly selected surface ice were collected with a sterilized stainless-steel scoop $(1-2 \mathrm{~cm}$ in depth). The collected ice samples in this study were taken from flat ablating bare-ice surfaces devoid of observable meltwater flow and rills. Sampling locations were chosen to represent the dominant bare-ice habitat in the ablation area of the glaciers, and avoided sampling of other microbial habitats (e.g., cryoconite). Areas rich in cryoconite holes, meltwater streams, and mounds of cryoconite or debris were excluded from the sampling strategy. The surface area from which bare-ice samples were taken was measured with an estimated accuracy of $\pm 4 \mathrm{~cm}^{2}$. The collected ice samples were melted and preserved as a $3 \%$ formalin v/v solution in clean $30 \mathrm{~mL}$ polyethylene bottles. All samples were transported to the Chiba University, Japan for further analysis.
The algal biomass of each site was represented by algal cell volume (biovolume) per unit area $\left(\mu \mathrm{L} \mathrm{m} \mathrm{m}^{-2}\right)$. Cell counts and estimations of cell volume were conducted with an optical microscope (BH-51, Olympus, Japan). The samples were initially stained with $0.5 \%$ erythrosine $(0.1 \mathrm{~mL}$ was added to $3 \mathrm{~mL}$ of sample) and ultrasonicated (20 and $100 \mathrm{kHz}$ ) for $5 \mathrm{~min}$ to loosen sediment particles. A volume of $50-1000 \mu \mathrm{L}$ of the sample water was passed through a hydrophilized PTFE membrane filter (pore size $0.45 \mu \mathrm{m}$, Millipore FHLC01300), which became transparent with water, and the number of cells on the filter was counted. Filamentous cyanobacteria were counted every $50 \mu \mathrm{m}$ of their filament since their cells were too small to be distinguished with confidence. From the cell number and filtered sample water volume, the cell (or unit filament) concentration (cells $\mathrm{mL}^{-1}$ ) of the sample was obtained. Mean cell volume derived from standard geometric properties was estimated by measuring the size of 50 - 100 cells for each taxa using microscopic photographs with an image processing software (ImageJ: Rasband, 2016). The total phototroph biomass was estimated by summing values obtained by multiplying cell concentrations by the mean cell volume. This calculation was done for each species at each site. Community structure was represented by the mean proportion of each species in five samples to the total phototroph volume at each sampling point. Based on the cell volume biomass, species diversity was calculated using Simpson's diversity index $D$ :

$$
D=\frac{1}{\sum_{i=1}^{S} P_{i}^{2}}
$$

where $S$ is the total number of species in the community, and $P_{i}$ is the proportion of the $i$ th species to the total algal biomass.

Total suspended solid sediment in the surface ice was quantified using the ice surface samples. A volume of $3 \mathrm{~mL}$ of the melted samples was dried and then remaining sediment was weighed. The mass of the solid particles in the melted ice $\left(\mathrm{g} \mathrm{L}^{-1}\right)$ were obtained.

Statistical analyses were performed using $\mathrm{R}$ Statistical Software, with the "vegan" package (R Core Team, 2017; Oksanen et al., 2017).

\section{RESULTS AND DISCUSSION}

\section{Meltwater Hydrochemistry}

Analyses of the major soluble ions in the surface melt water showed that nutrients including nitrogen and phosphorus were only trace level at all of study sites (Table $\mathbf{1}$ and Figure 2a). $\mathrm{NO}_{3}{ }^{-}$was detected only at the site AB2 $\left(0.01 \mu\right.$ eq $\left.\mathrm{L}^{-1}\right)$ and $\mathrm{NH}_{4}{ }^{+}$was only at the AB1 $\left(0.4 \mu \mathrm{eq} \mathrm{L}^{-1}\right)$, but they were both close to the detection limit. $\mathrm{Na}^{+}$and $\mathrm{Cl}^{-}$ions dominated the solute concentrations, ranging from 0.3 to $21.9 \mu \mathrm{eq} \mathrm{L}^{-1}$ (mean: $8.4 \mu \mathrm{eq} \mathrm{L}^{-1}$ ) and from 0.5 to $30.4 \mu \mathrm{eq} \mathrm{L}^{-1}$ (mean: $11.8 \mu \mathrm{eq}$ $\mathrm{L}^{-1}$ ), respectively (Figure $2 \mathbf{b}$ ). However, these two ions were significantly different among the study sites (One-way analysis of variance (ANOVA), $\mathrm{Na}^{+}: F=139.63, p=0.00<0.01 ; \mathrm{Cl}^{-}$: $F=125.58, p=0.00<0.01)$ and were higher at the sites AB3, PD1, 
TABLE 1 | Mean soluble ion concentrations $\left(\mu \mathrm{Eq} L^{-1}\right)$ in surface meltwater on the Svalbard glaciers.

\begin{tabular}{cccccccc}
\hline Site & $\mathrm{Na}^{+}$ & $\mathbf{C l}^{-}$ & $\mathbf{S O}_{\mathbf{4}}{ }^{2-}$ & $\mathbf{M g}^{2+}$ & $\mathbf{C a}^{2+}$ & $\mathbf{K}^{+}$ & $\mathbf{N H}_{\mathbf{4}}{ }^{+}$ \\
\hline AB1 & \multirow{2}{*}{1.8} & 2.9 & 0.4 & 1.5 & 3.2 & 0.7 & 0.4 \\
& & $(0.8)$ & $(0.2)$ & $(1.1)$ & $(3.1)$ & $(0.6)$ & \\
AB2 & 2.2 & 3.1 & 0.8 & 2.3 & 4.1 & 0.7 & - \\
& & $(0.4)$ & $(0.5)$ & $(1.8)$ & $(4.0)$ & $(0.7)$ & \\
AB3 & 21.9 & 30.4 & 2.9 & 1.9 & 2.1 & 0.2 & - \\
& & $(5.0)$ & $(0.2)$ & $(0.0)$ & $(1.1)$ & $(0.0)$ & \\
ML1 & 0.3 & 0.5 & - & 0.5 & 0.5 & - & - \\
& & $(0.2)$ & & $(0.5)$ & $(0.5)$ & & \\
ML2 & 4.6 & 6.9 & 1.0 & 0.9 & 0.7 & 0.1 & - \\
& & $(1.5)$ & $(0.4)$ & $(0.0)$ & $(0.5)$ & $(0.0)$ & \\
PD1 & 17.9 & 25.3 & - & 2.4 & 2.6 & 0.3 & - \\
& & $(4.4)$ & & $(0.0)$ & $(1.8)$ & $(0.0)$ & \\
PD2 & 9.7 & 13.7 & - & 1.6 & 1.6 & 0.1 & - \\
& & $(2.4)$ & & $(0.0)$ & $(1.2)$ & $(0.0)$ &
\end{tabular}

Non-sea salt concentration based on Na are shown in bracket. Values under detection level are not shown.

and PD2. They are most likely to be derived from windblown sea spray and their variation may arise from the effect local topography on their transport and deposition (e.g., Domine et al., 2004).

$\mathrm{Ca}^{2+}$ and $\mathrm{Mg}^{2+}$ concentrations were intermediate, ranging from 0.5 to $4.1 \mu$ eq $\mathrm{L}^{-1}$ (mean: $2.1 \mu$ eq $\mathrm{L}^{-1}$ ) and from 0.5 to $2.4 \mu \mathrm{eq} \mathrm{L}^{-1}$ (mean: $1.6 \mu$ eq $\mathrm{L}^{-1}$ ), respectively (Figure $2 \mathrm{c}$ ). Their non-sea salt fractions ranged $0-86 \%$ (mean: $33 \%$ ) for $\mathrm{Mg}^{2+}$ and $55-98 \%$ (mean: $80 \%$ ) for $\mathrm{Ca}^{2+}$ and they are likely to be derived from mineral dust on the glacier surface. The concentrations of the two ions were significantly different among the study sites (ANOVA, $\mathrm{Mg}^{2+}: F=49.84, p=0.00<0.01 ; \mathrm{Ca}^{2+}: F=51.74$, $p=0.00<0.01)$. The divalent cations were relatively elevated at the sites on Austre Brøggerbreen and Pedersenbreen (1.6 $4.1 \mu \mathrm{eq} \mathrm{L}^{-1}$ for $\mathrm{Ca}^{2+}$ and $1.6-2.4 \mu$ eq $\mathrm{L}^{-1}$ for $\mathrm{Mg}^{2+}$ ), but lower at the sites on Midtre Lovénbreen $\left(0.5-0.7 \mu \mathrm{eq} \mathrm{L}^{-1}\right.$ for $\mathrm{Ca}$ and $0.5-0.9 \mu$ eq $\mathrm{L}^{-1}$ for $\mathrm{Mg}$ ). These variations among the glaciers are probably due to difference in mineral loading on each glacier surface.

Total solid sediment in the surface ice ranged from 0.17 to $7.03 \mathrm{~g} \mathrm{~L}^{-1}$ (Figure 3) and was significantly different among the study sites (ANOVA, $F=7.4101, p=0.00018<0.01$ ). Sediment concentration mirrored the spatial pattern found for $\mathrm{Ca}^{2+}$ and $\mathrm{Mg}^{2+}$, being generally higher at the sites on Austre Brøggerbreen and Pedersenbreen $\left(0.90-7.03 \mathrm{~g} \mathrm{~L}^{-1}\right)$, but lower at the sites on Midtre Lovénbreen $\left(0.17-1.41 \mathrm{~g} \mathrm{~L}^{-1}\right)$. The surface ice at the lowerest sites on Austre Brøggerbreen contained highest sediment $\left(7.03 \mathrm{~g} \mathrm{~L}^{-1}\right)$.

\section{Phototrophs Observed on the Glaciers}

The seven taxa of phototrophs were observed on the glacier surface with a microscope (Table 2 and Figure 4). They included green alga and cyanobacteria, which have been commonly found over the Arctic glaciers. Mesotaenium bregrenii and Ancylonema nordenskiöldii are common desmids algae on glaciers over the Arctic regions (Remias et al., 2012a,b; Tanaka et al., 2016; Williamson et al., 2018). Cylindrocystis brébissonii has been found
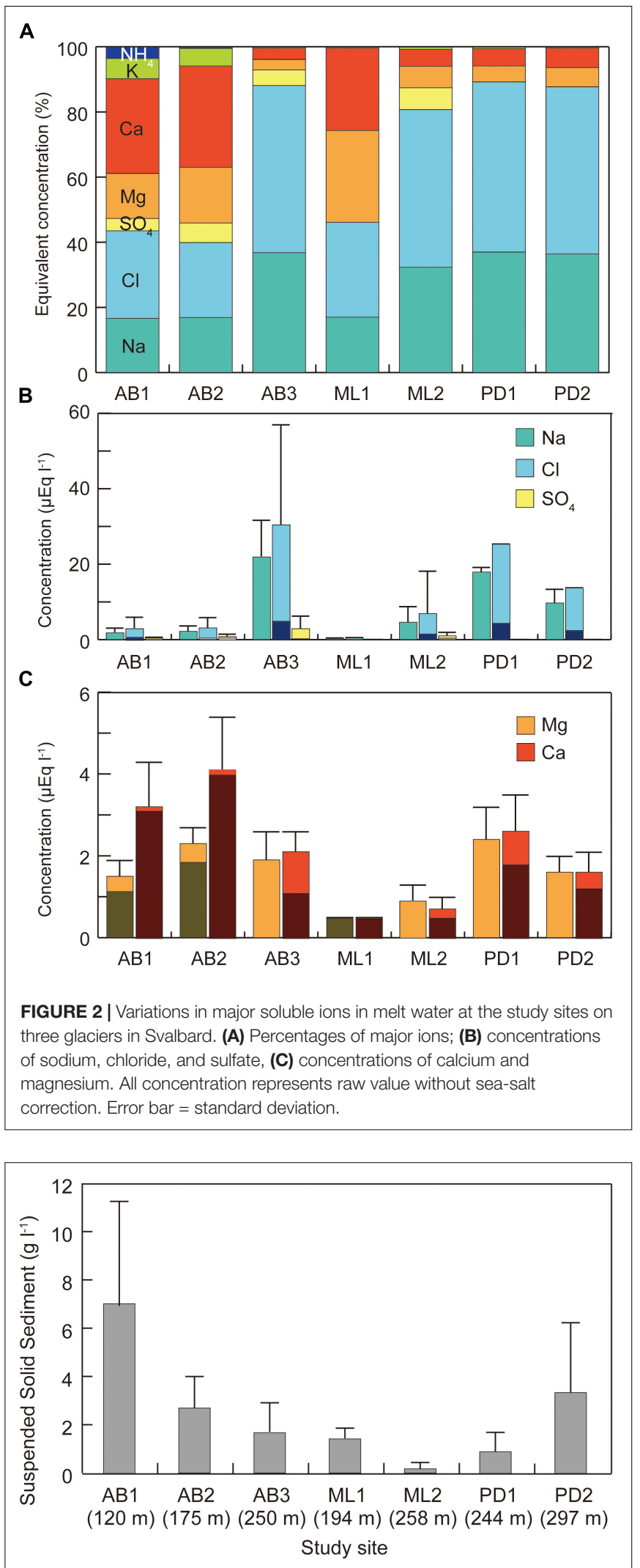

FIGURE 3 | Suspended solid sediment in surface ice at the study sites on three glaciers in Svalbard. 
TABLE 2 | Taxa of phototrophs observed with a microscope on the Svalbard glaciers.

\begin{tabular}{|c|c|c|}
\hline Taxa & Size & Cell morphology \\
\hline $\begin{array}{l}\text { Mesotaenium } \\
\text { bregrenii }\end{array}$ & $\begin{array}{l}14.9 \pm 1.8 \mu \mathrm{m} \text { in length } \\
\text { and } 8.8 \pm 2.3 \mu \mathrm{m} \text { in } \\
\text { width }\end{array}$ & $\begin{array}{l}\text { Two flat chloroplasts and filled } \\
\text { with dark brownish pigments } \\
\text { (Figure } \mathbf{4 b} \text { ) }\end{array}$ \\
\hline $\begin{array}{l}\text { Ancylonema } \\
\text { nordenskiöldii }\end{array}$ & $\begin{array}{l}19.3 \pm 8.3 \mu \mathrm{m} \text { in length } \\
\text { and } 9.1 \pm 2.4 \mu \mathrm{m} \text { in } \\
\text { width }\end{array}$ & $\begin{array}{l}\text { Straight or slightly curved } \\
\text { filaments, consisting of } \\
\text { 2-20 cell (Figure } 4 a \text { ) }\end{array}$ \\
\hline $\begin{array}{l}\text { Cylindrocystis } \\
\text { brébissonii }\end{array}$ & $\begin{array}{l}34.7 \pm 6.0 \mu \mathrm{m} \text { in length, } \\
20.4 \pm 1.9 \mu \mathrm{m} \text { in width }\end{array}$ & $\begin{array}{l}\text { A cylindrical shaped alga with } \\
\text { rounded apices containing two } \\
\text { axial chloroplasts and one } \\
\text { pyrenoid (Figure } 4 \mathbf{d} \text { ) }\end{array}$ \\
\hline $\begin{array}{l}\text { Chlamydomonas } \\
\text { nivalis }\end{array}$ & $\begin{array}{l}13.3 \text { to } 23.0 \mu \mathrm{m} \text { in } \\
\text { diameter }\end{array}$ & $\begin{array}{l}\text { Spherical cell filled with red } \\
\text { pigments (Figure 4c) }\end{array}$ \\
\hline $\begin{array}{l}\text { Phormidesmis } \\
\text { priestleyi }\end{array}$ & $\begin{array}{l}1.5 \pm 0.2 \mu \mathrm{m} \text { in diameter } \\
\text { with thin sheath }\end{array}$ & $\begin{array}{l}\text { Trichome with thin sheath } \\
\text { (Figure } \mathbf{4 f} \text { ) }\end{array}$ \\
\hline $\begin{array}{l}\text { Oscillatoriaceae } \\
\text { cyanobacterium }\end{array}$ & $1.5 \pm 0.2 \mu \mathrm{m}$ in diameter & $\begin{array}{l}\text { Trichome with unclear cell wall } \\
\text { and sheath (Figure } \mathbf{4 e} \text { ) }\end{array}$ \\
\hline $\begin{array}{l}\text { Chlorooceae } \\
\text { cyanobacterium }\end{array}$ & $6.0 \pm 1.5 \mu \mathrm{m}$ in diameter & Coccoid cells \\
\hline
\end{tabular}

on the ice and soil in Arctic regions (e.g., Stibal et al., 2006; Kim et al., 2011). Chlamydomonas nivalis is usually found as a visible reddish bloom on snow surface over the Arctic region (Lutz et al., 2016).

There were at least two filamentous cyanobacterial taxa observed on the glaciers. One was an Oscillatoriaceae affiliated cyanobacterium. This is probably Phormidesmis priestleyi, which is the most common cyanobacterial taxon in Brøggerhalvøya cryoconite (Edwards et al., 2011) and indeed over the Arctic region (e.g., Chrismas et al., 2016; Gokul et al., 2016; Segawa et al., 2017). Another taxon was also Oscillatoriaceae cyanobacterium, but has a distinctive cell morphology (unclear sheath) from the $P$. priestleyi. The abundance of this taxon on the ice surface was generally smaller compared with that of $P$. priestleyi. Coccoid cyanobacteria (Chroococcaceae) was also observed.

Although molecular identification was not performed in this study, the phototrophs observed on the glaciers are likely the same species as found on other Arctic and sub-Arctic glaciers and which are dispersed across the glacierized areas in the circumArctic regions. Amplicon sequencing of eukaryotic 18S rRNA and ITS2 genes indicate the prevalence of similar taxa across the Arctic region; for instance, red pigmented algae are apparently cosmopolitan on Arctic glaciers (Lutz et al., 2016; Segawa et al., 2018), and A. nordenskiöldii are prevalent across Svalbard, Arctic Sweden, and Greenland Ice Sheet (Lutz et al., 2017, 2018). The biogeography of glacier cyanobacteria showed that there are common cyanobacterial phylotypes in the Arctic regions (Segawa et al., 2017). The phototrophs observed on the three glaciers in this study are likely to be derived from the atmosphere as has been suggested elsewhere (e.g., Price et al., 2009; Xiang et al., 2009).

\section{Cell Volume Biomass and Community Structure of Phototrophs}

The total cell volume biomass significantly varied among the study sites (Kruskal-Wallis test, $H=24.198, p=0.00<0.01$;

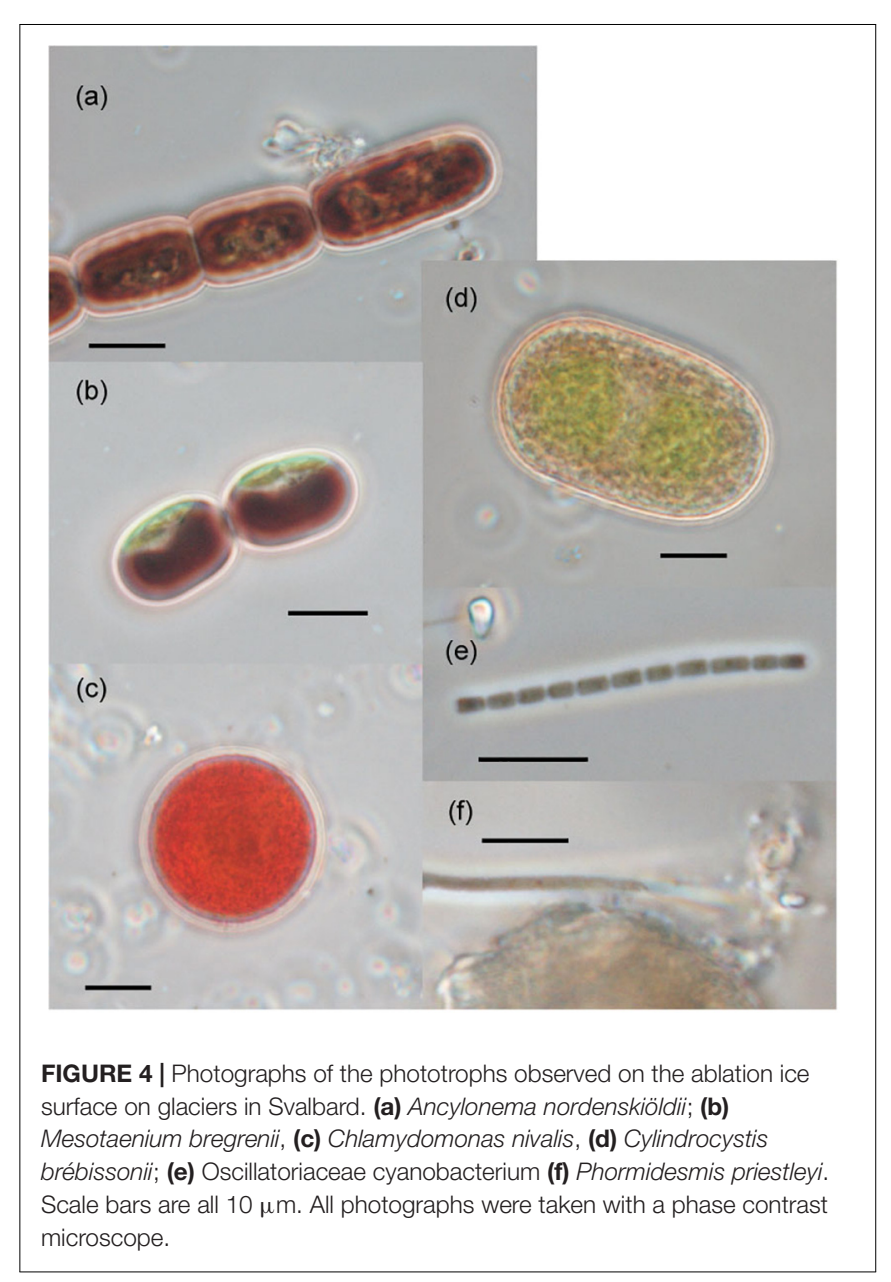

Figure 5), ranging from 4.0 to $932 \mu \mathrm{L} \mathrm{m}^{-2}$ (mean: $115 \mu \mathrm{L} \mathrm{m}^{-2}$ ). It was generally higher at the lower elevation sites on each glacier. The highest biomass was found at the lower site (ML1) of Midtre Lovénbreen $\left(473 \pm 318 \mu \mathrm{L} \mathrm{m}^{-2}\right)$.

The community structure was also significantly distinctive among the study sites [PER mutational Multivariate Analysis of Variance (PERMANOVA) using Bray-Curtis similarity index, Pseudo $F=8.160, p<0.001$; Figure 6a]. At the two sites on Midtre Lovénbreen, A. nordenskiöldii was highly dominant, accounting for more than $90 \%$ of the total biomass. On Pedersenbreen, $A$. nordenskiöldii was also dominant at both study sites, accounting for between 31 and $45 \%$ of the total biomass. The other green algal taxa were also prominent at these sites: $C y l$. brébissonii accounted for $24 \%$ of the biomass at site PD1, and $C d$. nivalis for $37 \%$ at PD2. In contrast, on Austre Brøggerbreen, the algal community structure was characterized by the dominance of cyanobacteria. The two taxa of cyanobacteria ( $P$. priestleyi and Oscillatoriaceae cyanobacterium) accounted for $7-64 \%$ of the total biomass on Austre Brøggerbreen, but only $1-12 \%$ on Midtre Lovénbreen and Pedersenbreen. In particular, they were most abundant at the lower two sites on Austre Brøggerbreen (AB1 and AB2: $35-65 \%$ ), and P. priestleyi was more abundant than Oscillatoriaceae cyanobacterium. A. nordenskiöldii was only for $4-42 \%$ at the three sites on this glacier. $C d$. nivalis 


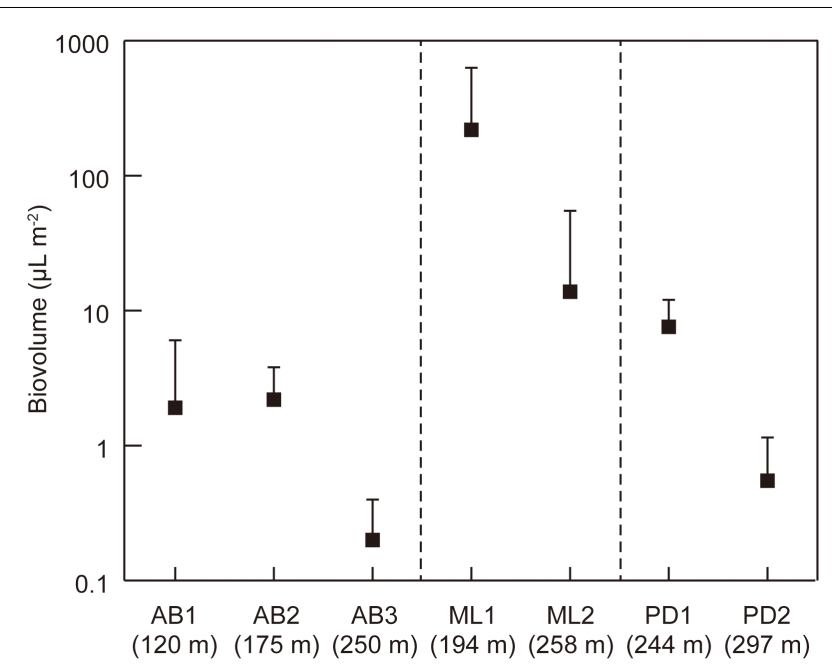

FIGURE 5 | Variations in total cell volume biomass (biovolume) of phototrophs at the study sites on the three glaciers in Svalbard. AB1-3, Austre Brøggerbreen; ML1-2, Midtre Lovénbreen; PD1-2, Pedersenbreen. Error bar = standard deviation.

was also intermediately dominant on the Austre Brøggerbreen, accounting for $15-25 \%$ in the total.

The diversity index $(D)$ showed significant difference between the study sites (Figure 6b; Kruskal-Wallis rank test, $H=20.453$, $p=0.0023<0.01)$. $D$ was lower at two sites on Midtre Lovénbreen $(1.16-1.22)$, but in contrast, it was higher at the sites on other two glaciers (3.64 - 4.61 for Austre Brøggerbreen; 3.53 3.90 for Pedersenbreen).

Results shows that the phototroph communities were distinctive among the three adjacent glaciers studied, despite the similarity in their geographical setting. Although various surface habitats such as cryoconite holes, meltwater rills and streams, cryoconite or debris mounds, were all present on the ice at each site, the sampling strategy targeting generally flat, bare-ice mitigated potential contamination from these habitats. Furthermore, the phototrophs observed on the glaciers appeared to be the species widely distributed in Arctic region, and thus the difference in their community is unlikely to be explained by dispersal process for each species. The number of sites per glacier was limited during this study, precluding the ability to characterize heterogeneity in phototroph communities at the glacier scale. However, given differences in phototroph community compositions indicated by our statistical analyses, we explore potential contributing factors to such variation below.

\section{Potential Contributing Factors in Distinctive Phototroph Communities on Bare Ice Surface}

The major soluble ions in the surface melt water showed that there was no significant difference in hydrochemical conditions among the three glaciers, suggesting that local, meltwater-derived nutrients alone are unlikely to dictate the community structure.

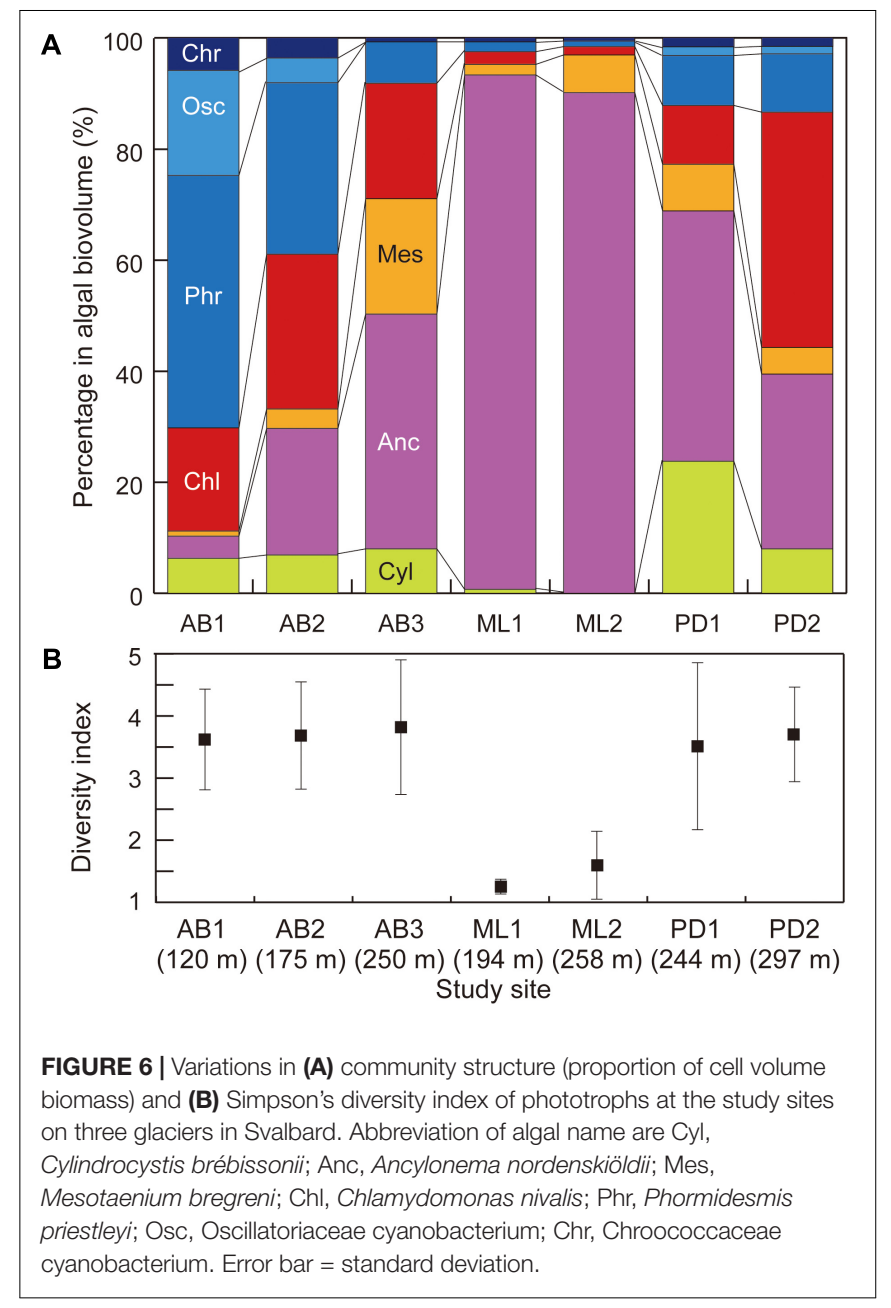

Both nitrate and ammonium concentrations were low (less than $6 \mu$ eq $\mathrm{L}^{-1}$ ) and phosphate was also under detection level (less than $1 \mu \mathrm{eq} \mathrm{L}^{-1}$ ) at all of study sites on the glaciers. Previous studies have suggested that phosphorus or nitrogen could affect microbial growth on glaciers in Svalbard (e.g., Stibal et al., 2008; Zarsky et al., 2013); however, these studies focused only on microbes in cryoconite holes, rather than the phototrophs on the ablating bare-ice surface. Nutrients in the water film surrounding ice crystals at the bare-ice surface and within the weathering crust, where the phototrophs grow, can be more dynamic compared with relatively static environment of cryoconite holes (Christner et al., 2018).

The difference of calcium and magnesium concentrations suggests that the surface ice mineral loading varies between the glaciers, and may be, at least partially, responsible for the variation in the phototroph community. Mineral dusts in the surface ice were relatively abundant at the sites on Austre Brøggerbreen and Pedersenbreen, but less so on Midtre Lovénbreen. Mineral particles can be used to form cryoconite granules by filamentous cyanobacteria, and accordingly abundant minerals may promote the growth of cyanobacteria on the bare-ice surface (e.g., Takeuchi et al., 
2001; Langford et al., 2010; Zarsky et al., 2013). On Austre Brøggerbreen, elevated abundance of cyanobacteria and soil sediment in the surface ice was greater in the two lower elevation sites, supporting this idea. Furthermore, the sediment abundance was not correlated with the total phototroph biomass, but was significantly correlated with the biomass of two filamentous bacteria (Pearson's correlation coefficient: P. priestleyi: $r=0.642, p=0.000<0.001$; Oscillatoriaceae cyanobacterium: $r=0.629, p=0.000<0.001)$. Therefore, the dominance of cyanobacteria in the community on Austre Brøggerbreen may be driven by the abundant mineral dust in the surface ice.

At Austre Brøggerbreen, a structural study (Jennings, 2017) suggests terminal grade sediment at the ice surface indicates a subglacial source. In the lower ablation area of the glacier, reddish and brown fine mineral sediment was observed (Figure 7a), which compared well to similar coloration of suspended sediment in proglacial streams and moraine content and reflects the Carboniferous sandstone and shale bedrock at lower elevations (Hjelle, 1993; Harland et al., 1997; Glasser and Hambrey, 2001). The emergent sediment delivery to surface is not an active process, but relict from previously more dynamic glacial conditions (Jennings et al., 2016; Jennings, 2017). However, an additional source of sediment on the surface may arise from the mobilization of moraine sediments from the progressively exposed unconsolidated margins (Porter et al., 2010).

On Pedersenbreen, a west tributary joins the main tongue at the elevation just above the site $\mathrm{PB} 2$, which results in the presence of an exposed medial moraine feature that give a potential source of dust and calcium and magnesium ions in meltwater on ice exposed to lower part of ablation area (Figure 1d). Since the percentage of cyanobacteria in the algal community on Pedersenbreen was not as high as that seen on Austre Brøggerbreen, the delivery of sediment to the glacier surface may be reduced, and the effect of minerals may be more limited. The algal community on Pedersenbreen was characterized by the higher percentage of snow algae, $C d$. nivalis, which has also been reported on other Arctic or sub-Arctic glaciers (e.g., Takeuchi, 2001). The sampling sites were higher elevation than on the other glaciers, and so the duration of bare-ice conditions following snowmelt and prior to sampling may have been reduced. The alga may be transferred from remaining snow patches above the sampling sites as these algae usually grow on remaining winter snow.

Supraglacial meltwater drainage on the three glaciers may also affect the phototroph community. For example, in response to its geometry and recent thinning, Austre Brøggerbreen has a drainage system that is more interrupted by moulins and crevasse traces (Jennings et al., 2016), while in contrast, Midtre Lovénbreen is characterized by a number of deeply incised parallel supraglacial channels fed by dendritic rill networks that extend over the majority of the glacier's ablation area (Rippin et al., 2015; Figure 7b) and Pedersenbreen exhibits a more dense drainage pattern associated with ice structure oriented downglacier but oblique to the centerline (Figure 7c). Such contrasts in supraglacial hydrology have previously been suggested to cause distinctiveness in bacterial communities in

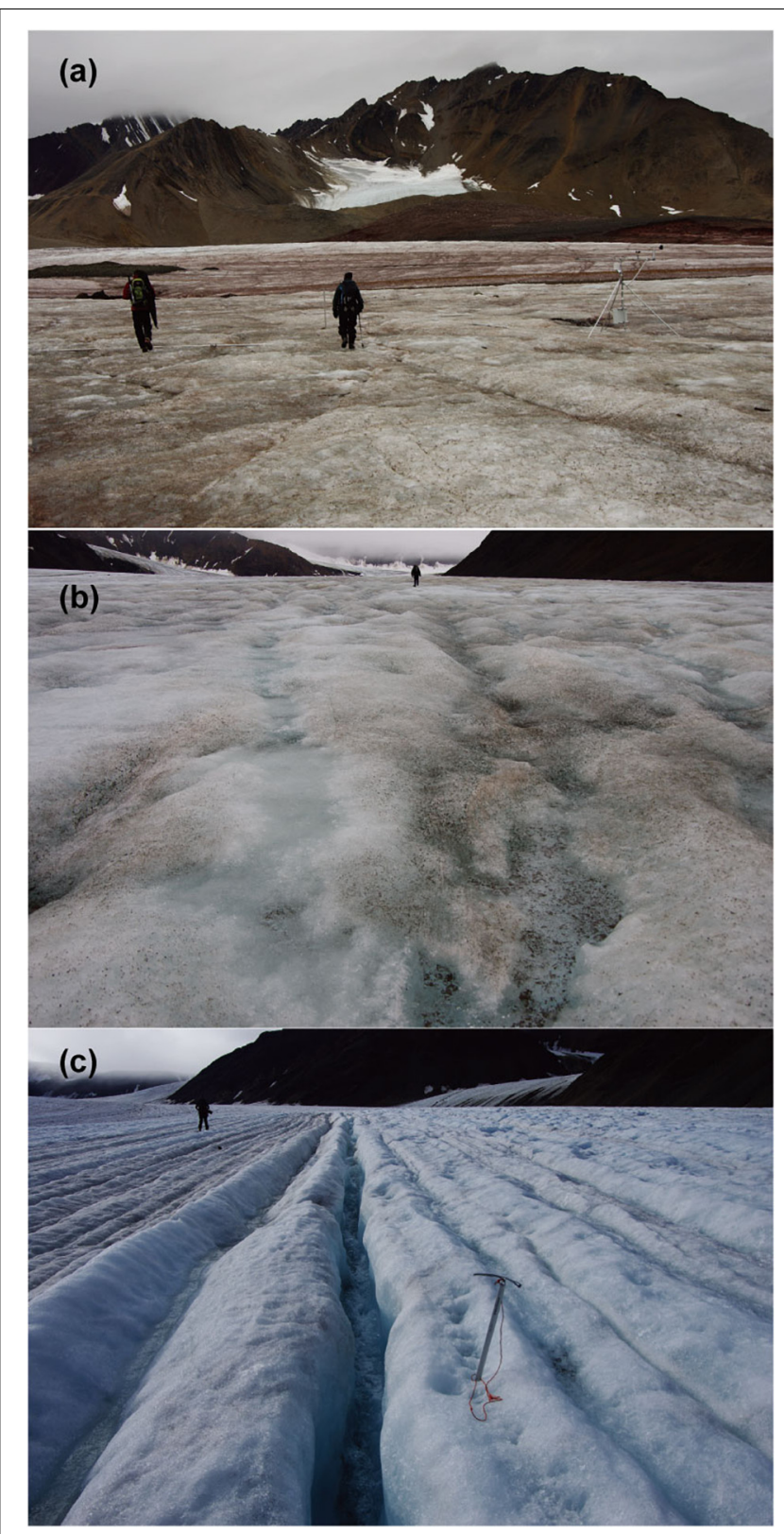

FIGURE 7 | Photographs of typical bare-ice surface on the three glaciers in Svalbard. (a) Austre Brøggerbreen; (b) Midtre Lovénbreen; (c) Pedersenbreen.

cryoconite holes among the glaciers on Brøggerhalvøya (Edwards et al., 2011). Although a more detailed hydrological study is necessary, the data presented here indicate the potential role of contrasts in glacier-scale and local supraglacial drainage in influencing phototrophic microbial communities.

The distinct phototroph communities on the glaciers infer two different potential processes of the darkening on the ice surface. On Midtre Lovénbreen, the algal cells of $A$. nordenskiöldii could be most effective as a light absorbing impurity on the surface since the algal cells are usually filled with dark-reddish pigments (Remias et al., 2012a). Acceleration of ice melt rates by 
A. nordenskiöldii has also been reported on glaciers in Greenland (Stibal et al., 2017) and on glaciers in east Siberia (Takeuchi et al., 2015). Alternatively, dispersed cryoconite is more effective than the green algal cells on Austre Brøggerbreen, where filamentous cyanobacteria accounted for a major part of the phototroph community. This process corresponds with a part of glaciers in northwest Greenland (Takeuchi et al., 2014; Uetake et al., 2016), and are more common in Asian glaciers (Takeuchi et al., 2001; Takeuchi and Li, 2008). The difference in these two processes appears to be principally determined by the abundance of mineral loading on the glacier surface. The tectonic history of Brøggerhalvøya results in subtle contrasts in the bedrock and ridgeline geologies between the glaciers (Hjelle, 1993; Svendsen et al., 2002). The catchment geometries and former glacier activity have led to marked contrasts in the structural glaciology and the associated supraglacial hydrological configuration and emergence of sediment in the bare-ice area. The glacier thinning rates are also more marked at Austre Broggerbreen (e.g., Barrand et al., 2010), which may be partially augmented by the microbial darkening effect. However, in order to understand the process of the biological albedo reduction, further studies on the physical factors, such as sediment dynamics and meltwater drainage, that define the phototroph community across supraglacial ablation areas are necessary.

\section{CONCLUSION}

The phototroph communities on the ablation ice surface of three valley glaciers on Brøggerhalvøya, Svalbard, consisted mainly of 7 taxa of green algae and cyanobacteria and were distinct between the glaciers. The community was characterized by the greater total biomass and high dominance of single green algae A. nordenskiöldii for Midtre Lovénbreen, by dominance of cyanobacteria for Austre Brøggerbreen, and by composition of diverse green algae for Pedersenbreen. There was no significant difference in meltwater hydrochemistry, but the concentrations of non-sea salt calcium and magnesium differed among the glaciers. This suggests that mineral loading on the glacier surface varied among the glaciers since these two solutes are

\section{REFERENCES}

Ai, S., Wang, Z., Holmen, K., Tan, Z., Zhou, C., and Sun, W. (2014). Topography, ice thickness and ice volume of the glacier pedersenbreen in svalbard, using GPR and GPS. Pol. Res. 33:18533. doi: 10.3402/polar.v33.18533

Anesio, A. M., Hodson, A., Fritz, A., Psenner, R., and Sattler, B. (2009). High microbial activity on glacier: importance to the global carbon cycle. Global Change Biol. 15, 955-960. doi: 10.1111/j.1365-2486.2008.01758.x

Barrand, N. E., James, T. D., and Murray, T. (2010). Spatio-temporal variability in elevation changes of two high-arctic valley glaciers. J. Glaciol. 56, 771-780. doi: $10.3189 / 002214310794457362$

Björnsson, H., Gjessing, Y., Hamran, S. E., Hagen, J. O., LiestøL, O., Pálsson, F., et al. (1996). The thermal regime of sub-polar glaciers mapped by multi-frequency radio-echo sounding. J. Glaciol. 42, 23-32. doi: 10.3189/ S0022143000030495

Cameron, K. A., Hodson, A. J., and Osborn, A. M. (2012). Structure and diversity of bacterial, eukaryotic and archaeal communities in glacial cryoconite generally derived from mineral dust. Results from this study suggest that the phototroph communities may be associated with the structural history of the glaciers and their thinning rates. Specifically, the emergent structures, which are a record of past ice dynamics, may control the delivery of en- or subglacial debris to the ice surface as well as modulating supraglacial hydrology through governing the glacier-wide drainage system configuration and influencing the nature of the weathering crust. The distinct phototroph communities on the glaciers suggest the potential for spatially varied processes of the darkening on the ice surface, therefore it is critical to improve current understanding of the factors affecting the phototroph community on the ablation surfaces.

\section{AUTHOR CONTRIBUTIONS}

NT, TI-F, and AE designed the project. NT, TI-F, AE, and SR conducted field work in Svalbard. NT, ST, and YK analyzed algal community and soluble ions in the samples. NT, TI-F, and AE wrote the manuscript.

\section{FUNDING}

This study was financially supported by the Japan Society for the Promotion of Science (JSPS) Grant-in-Aids (23221004, 26247078, 26241020, and 16H01772), and access to the UK Arctic Station for NT, SR, TI-F, and AE was supported by NERC (NE/K000942/1 to AE). TI-F acknowledges NERC Grant NE/M021025/1, and Leverhulme Trust Fellowship (RF-2018584/4). NT, TI-F, and AE also recognize Great Britain Sasakawa Foundation Grant \#3998. SR recognizes the Freshwater Biological Association's Hugh Cary Gilson Memorial award 2013.

\section{ACKNOWLEDGMENTS}

We thank to James Wake and Nicholas Cox for their support of our fieldwork in Kongsfjord. We also thank to two reviewers for valuable suggestions, which improved the manuscript.

holes from the Arctic and the Antarctic. FEMS Microbiol. Ecol. 82, 254-267. doi: 10.1111/j.1574-6941.2011.01277.x

Chrismas, N. A., Barker, G., Anesio, A. M., and Sánchez-Baracaldo, P. (2016). Genomic mechanisms for cold tolerance and production of exopolysaccharides in the Arctic cyanobacterium Phormidesmis priestleyi BC1401. BMC Genomics 17:533. doi: 10.1186/s12864-016-2846-4

Christner, B. C., Lavender, H. F., Davis, C. L., Oliver, E. E., Neuhaus, S. U., Myers, K. F., et al. (2018). Microbial processes in the weathering crust aquifer of a temperate glacier. Cryosphere 12, 3653-3669. doi: 10.5194/tc-12-3653-2018

Cook, J. M., Edwards, A., Takeuchi, N., and Irvine-Fynn, T. (2016a). Cryoconite: the dark biological secret of the cryosphere. Prog. Phys. Geograp. 40, 66-111. doi: 10.1177/0309133315616574

Cook, J. M., Hodson, A. J., and Irvine-Fynn, T. D. L. (2016b). Supraglacial weathering crust dynamics inferred from cryoconite hole hydrology. Hydrol. Process. 30, 433-446. doi: 10.1002/hyp.10602

Cook, J. M., Hodson, A. J., Anesio, A. M., Hanna, E., Yallop, M., Stibal, M., et al. (2012). An improved estimate of microbially mediated carbon fluxes 
from the Greenland ice sheet. J. Glaciol. 58:1098. doi: 10.3189/2012JoG 12J001

Domine, F., Sparapani, R., Ianniello, A., and Beine, H. J. (2004). The origin of sea salt in snow on Arctic sea ice and in coastal regions. Atmos. Chem. Phys. 4, 2259-2271. doi: 10.5194/acp-4-2259-2004

Edwards, A., Anesio, A. M., Rassner, S. M., Sattler, B., Hubbard, B., Perkins, W. T., et al. (2011). Possible interactions between bacterial diversity, microbial activity and supraglacial hydrology of cryoconite holes in Svalbard. ISME J. 5, 150-160. doi: 10.1038/ismej.2010.100

Edwards, A., Douglas, B., Anesio, A. M., Rassner, S. M., Irvine-Fynn, T. D., Sattler, B., et al. (2013). A distinctive fungal community inhabiting cryoconite holes on glaciers in Svalbard. Fungal Ecol. 6, 168-176. doi: 10.1016/j.funeco. 2012.11.001

Glasser, N. F., and Hambrey, M. J. (2001). Styles of sedimentation beneath Svalbard valley glaciers under changing dynamic and thermal regimes. J. Geol. Soc. 158, 697-707. doi: 10.1144/jgs.158.4.697

Gokul, J. K., Hodson, A. J., Saetnan, E. R., Irvine-Fynn, T. D., Westall, P. J., Detheridge, A. P., et al. (2016). Taxon interactions control the distributions of cryoconite bacteria colonizing a High Arctic ice cap. Mol. Ecol. 25, 3752-3767. doi: $10.1111 / \mathrm{mec} .13715$

Hagen, J. O., Liestøl, O., Roland, E., and Jørgensen, T. (1993). Glacier Atlas of Svalbard and Jan Mayen. Oslo: Norsk Polarinstitutt Meddelelser no 129, 141.

Hambrey, M. J., and Lawson, W. (2000). Structural styles and deformation fields in glaciers: a review. Geol. Soc. Lond. Spec. Publ. 176, 59-83. doi: 10.1144/GSL.SP. 2000.176.01.06

Harland, W. B., Anderson, L. M., Manasrah, D., Butterfield, N. J., Challinor, A., Doubleday, P. A., et al. (1997). The geology of svalbard. Geol. Soc. Lond. 354, $15-31$.

Hjelle, A. (1993). Geology of Svalbard. Oslo: Norsk Polarinstitutt, 1-165.

Hodson, A., Anesio, A. M., Ng, F., Watson, R., Quirk, J., Irvine-Fynn, T., et al. (2007). A glacier respires: quantifying the distribution and respiration CO2 flux of cryoconite across an entire Arctic supraglacial ecosystem. J. Geophys. Res. Biogeosci. 112:G4. doi: 10.1029/2007JG000452

Hodson, A., Anesio, A. M., Tranter, M., Fountain, A., Osborn, M., Priscu, J., et al. (2008). Glacial ecosystems. Ecol. Monogr. 78, 41-67. doi: 10.1890/07-0187.1

Holland, H. D. (1978). The Chemistry of the Atmosphere and Oceans. New York, NY: Wiley-Intersciences, 1-369.

Hotaling, S., Hood, E., and Hamilton, T. L. (2017). Microbial ecology of mountain glacier ecosystems: biodiversity, ecological connections and implications of a warming climate. Environ. Microbiol. 19, 2935-2948. doi: 10.1111/1462-2920. 13766

Hudleston, P. J. (2015). Structures and fabrics in glacial ice: a review. J. Struct. Geol. 81, 1-27. doi: 10.1016/j.jsg.2015.09.003

Irvine-Fynn, T. D., and Edwards, A. (2014). A frozen asset: the potential of flow cytometry in constraining the glacial biome. Cytomet. Part A 85, 3-7. doi: 10.1002/cyto.a.22411

Irvine-Fynn, T. D. L., Edwards, A., Newton, S., Langford, H., Rassner, S. M., Telling, J., et al. (2012). Microbial cell budgets of an Arctic glacier surface quantified using flow cytometry. Environ. Microbial. 14, 2998-3012. doi: 10. $1111 / j .1462-2920.2012 .02876 . x$

Jennings, S. J. (2017). Origins of Foliations and Related Phenomena in Valley Glaciers and Ice Sheets. PhD Thesis, Aberystwyth University, Aberystwyth.

Jennings, S. J., Hambrey, M. J., Glasser, N. F., James, T. D., and Hubbard, B. (2016). Structural glaciology of Austre Brøggerbreen, northwest Svalbard. J. Maps 12, 790-796. doi: 10.1080/17445647.2015.1076744

Kim, G. H., Klochkova, T. A., Han, J. W., Kang, S. H., Choi, H. G., Chung, K. W., et al. (2011). Freshwater and Terrestrial Algae from Ny-Ålesund and Blomstrandhalvøya Island (Svalbard). Arctic64, 25-31. doi: 10.14430/arctic 4077

Langford, H., Hodson, A., Banwart, S., and Bøggild, C. (2010). The microstructure and biogeochemistry of Arctic cryoconite granules. Ann. Glaciol. 51, 87-94. doi: $10.3189 / 172756411795932083$

Lutz, S., Anesio, A. M., Edwards, A., and Benning, L. G. (2017). Linking microbial diversity and functionality of arctic glacial surface habitats. Environ. Microbiol. 19, 551-565. doi: 10.1111/1462-2920.13494

Lutz, S., Anesio, A. M., Raiswell, R., Edwards, A., Newton, R. J., Gill, F., et al. (2016). The biogeography of red snow microbiomes and their role in melting arctic glaciers. Nat. Commun. 7:11968. doi: 10.1038/ncomms11968
Lutz, S., McCutcheon, J., McQuaid, J. B., and Benning, L. G. (2018). The diversity of ice algal communities on the Greenland Ice Sheet as revealed by oligotyping. Microb. Genom. doi: 10.1099/mgen.0.000159 [Epub ahead of print].

Mader, H. M., Pettitt, M. E., Wadham, J. L., Wolff, E. W., and Parkes, R. J. (2006). Subsurface ice as a microbial habitat. Geology 34, 169-172. doi: 10.1130/G2 2096.1

Müller, F., and Keeler, C. M. (1969). Errors in short-term ablation measurements on melting ice surfaces. J. Glaciol. 8, 91-105. doi: 10.3189/S0022143000020785

Nuth, C., Kohler, J., König, M., Deschwanden, A. V., Hagen, J. O. M., Kääb, A., et al. (2013). Decadal changes from a multi-temporal glacier inventory of Svalbard. Cryosphere 7, 1603-1621. doi: 10.5194/tc-7-1603-2013

Oksanen, J. F., Blanchet, G., Friendly, M., Kindt, R., Legendre, P., McGlinn, D., et al. (2017). Vegan: Community Ecology Package. R Package Version 2.4-3. Available at: https://CRAN.R-project.org/package=vegan

Porter, P. R., Vatne, G., Ng, F., and Irvine-fynn, T. D. (2010). Ice-marginal sediment delivery to the surface of a high-Arctic glacier: Austre Brøggerbreen, Svalbard. Geografiska Ann. Ser. A Phys. Geograp. 92, 437-449. doi: 10.1111/j.1468-0459. 2010.00406.x

Price, P. B., Rohde, R. A., and Bay, R. C. (2009). Fluxes of microbes, organic aerosols, dust, sea-salt $\mathrm{Na}$ ions, non-sea-salt $\mathrm{Ca}$ ions, and methanesulfonate onto Greenland and Antarctic ice. Biogeosciences 6, 479-486. doi: 10.5194/bg6-479-2009

R Core Team (2017). R: A Language and Environment for Statistical computing. Vienna: R Foundation for Statistical Computing. Available at: https://www.Rproject.org/.

Rasband, W. S. (2016). ImageJ. Bethesda, MD: U.S. National Institutes of Health. Available at: https://imagej.nih.gov/ij/.

Remias, D., Holzinger, A., Aigner, S., and Lütz, C. (2012a). Ecophysiology and ultrastructure of Ancylonema nordenskiöldii (Zygnematales, Streptophyta), causing brown ice on glaciers in Svalbard (high arctic). Polar Biol. 35, 899-908. doi: 10.1007/s00300-011-1135-6

Remias, D., Schwaiger, S., Aigner, S., Leya, T., Stuppner, H., and Lütz, C. (2012b). Characterization of an UV-and VIS-absorbing, purpurogallin-derived secondary pigment new to algae and highly abundant in Mesotaenium berggrenii (Zygnematophyceae, Chlorophyta), an extremophyte living on glaciers. FEMS Microbial. Ecol. 79, 638-648. doi: 10.1111/j.1574-6941.2011. 01245.x

Rippin, D. M., Pomfret, A., and King, N. (2015). High resolution mapping of supraglacial drainage pathways reveals link between micro-channel drainage density, surface roughness and surface reflectance. Earth Surf. Process. Landforms 40, 1279-1290. doi: 10.1002/esp.3719

Rippin, D. M., Willis, I. C., Arnold, N. S., Hodson, A. J., and Brinkhaus, M. (2005). Spatial and temporal variations in surface velocity and basal drag across the tongue of the polythermal glacier midre Lovénbreen, Svalbard. J. Glaciol. 51, 588-600. doi: 10.3189/172756505781829089

Ryan, J. C., Hubbard, A., Stibal, M., Irvine-Fynn, T. D., Cook, J., Smith, L. C., et al. (2018). Dark zone of the greenland ice sheet controlled by distributed biologically-active impurities. Nat. Commun. 9:1065. doi: 10.1038/s41467-01803353-2

Säwström, C., Mumford, P., Marshall, W., Hodson, A., and Laybourn-Parry, J. (2002). The microbial communities and primary productivity of cryoconite holes in an Arctic glacier (Svalbard 79 N). Polar Biol. 25, 591-596. doi: 10.1007/ s00300-002-0388-5

Segawa, T., Matsuzaki, R., Takeuchi, N., Akiyoshi, A., Navarro, F., Sugiyama, S., et al. (2018). Bipolar dispersal of red-snow algae. Nat. Commun. 9:3094. doi: 10.1038/s41467-018-05521-w

Segawa, T., Yonezawa, T., Edwards, A., Akiyoshi, A., Tanaka, S., Uetake, J., et al. (2017). Biogeography of cryoconite forming cyanobacteria on polar and Asian glaciers. J. Biogeogr. 44, 2849-2861. doi: 10.1111/jbi.13089

Singh, P., and Singh, S. M. (2012). Characterization of yeast and filamentous fungi isolated from cryoconite holes of Svalbard, Arctic. Polar Biol. 35, 575-583. doi: 10.1007/s00300-011-1103-1

Stevens, I. T., Irvine-Fynn, T. D., Porter, P. R., Cook, J. M., Edwards, A., Smart, M., et al. (2018). Near-surface hydraulic conductivity of northern hemisphere glaciers. Hydrol. Proc. 32, 850-865. doi: 10.1002/hyp.11439

Stibal, M., Box, J. E., Cameron, K. A., Langen, P. L., Yallop, M. L., Mottram, R. H., et al. (2017). Algae drive enhanced darkening of bare-ice on the Greenland ice sheet. Geophys. Res. Lett. 44, 11463-11471. doi: 10.1002/2017GL075958 
Stibal, M., Šabacká, M., and Kaštovská, K. (2006). Microbial communities on glacier surfaces in Svalbard: impact of physical and chemical properties on abundance and structure of cyanobacteria and algae. Microb. Ecol. 52:644. doi: 10.1007/s00248-006-9083-3

Stibal, M., Šabacká, M., and Žárský, J. (2012). Biological processes on glacier and ice sheet surfaces. Nat. Geosci. 5, 771-774. doi: 10.1038/ngeo1611

Stibal, M., Tranter, M., Telling, J., and Benning, L. G. (2008). Speciation, phase association and potential bioavailability of phosphorus on a Svalbard glacier. Biogeochemistry 90, 1-13. doi: 10.1007/s10533-008-9226-3

Svendsen, H., Beszczynska-Møller, A., Hagen, J. O., Lefauconnier, B., Tverberg, V., Gerland, S., et al. (2002). The physical environment of KongsfjordenKrossfjorden, an Arctic fjord system in Svalbard. Polar Res. 21, 133-166. doi: 10.3402/polar.v21i1.6479

Takeuchi, N. (2001). The altitudinal distribution of snow algae on an Alaska glacier (Gulkana Glacier in the Alaska Range). Hydrol. Process. 15, 3447-3459. doi: 10.1002/hyp.1040

Takeuchi, N., Fujisawa, Y., Kadota, T., Tanaka, S., Miyairi, M., Shirakawa, T., et al. (2015). The effect of impurities on the surface melt of a glacier in the Suntar-Khayata mountain range, Russian Siberia. Front. Earth Sci. 3:82. doi: 10.3389/feart.2015.00082

Takeuchi, N., Kohshima, S., and Seko, K. (2001). Structure, formation, darkening process of albedo reducing material (cryoconite) on a Himalayan glacier: a granular algal mat growing on the glacier. Arct. Antarct Alp. Res. 33, 115-122. doi: $10.2307 / 1552211$

Takeuchi, N., and Li, Z. (2008). Characteristics of surface dust on Ürümqi glacier No. 1 in the Tien Shan mountains, China. Arct. Antaract Alp. Res. 40, 744-750. doi: 10.1657/1523-0430(07-094)[TAKEUCHI]2.0.CO;2

Takeuchi, N., Nagatsuka, N., Uetake, J., and Shimada, R. (2014). Spatial variations in impurities (cryoconite) on glaciers in northwest Greenland. Bull. Glaciol. Res. 32, 85-94. doi: 10.5331/bgr.32.85

Tanaka, S., Takeuchi, N., Miyairi, M., Fujisawa, Y., Kadota, T., Shirakawa, T., et al. (2016). Snow algal communities on glaciers in the Suntar-Khayata Mountain Range in eastern Siberia, Russia. Polar Sci. 10, 227-238. doi: 10.1016/j.polar. 2016.03.004

Uetake, J., Tanaka, S., Segawa, T., Takeuchi, N., Nagatsuka, N., Motoyama, H., and Aoki, T. (2016). Microbial community variation in cryoconite granules on Qaanaaq Glacier, NW Greenland. FEMS Microbiol. Ecol. 92:fiw127. doi: 10.1093/femsec/fiw127
Vonnahme, T. R., Devetter, M., Žárský, J. D., Šabacká, M., and Elster, J. (2016). Controls on microalgal community structures in cryoconite holes upon high Arctic glaciers. Svalbard. Biogeosci. 13, 659-674. doi: 10.5194/bgd-12-117512015

Williamson, C. J., Anesio, A. M., Cook, J., Tedstone, A., Poniecka, E., Holland, A., et al. (2018). Ice algal bloom development on the surface of the Greenland Ice Sheet. FEMS Microbiol. Ecol. 94:fiy025. doi: 10.1093/femsec/ fiy025

Xiang, S. R., Shang, T. C., Chen, Y., and Yao, T. D. (2009). Deposition and postdeposition mechanisms as possible drivers of microbial population variability in glacier ice. FEMS Microbiol. Ecol. 70, 165-176. doi: 10.1111/j.15746941.2009.00759.x

Yallop, M. L., Anesio, A. M., Perkins, R. G., Cook, J., Telling, J., Fagan, D., et al. (2012). Photophysiology and albedo-changing potential of the ice algal community on the surface of the Greenland ice sheet. ISME J. 6, 2302-2313. doi: 10.1038/ismej.2012.107

Yoshimura, Y., Kohshima, S., and Ohtani, S. (1997). A community of snow algae on a Himalayan glacier: change of algal biomass and community structure with altitude. Arct. Alp. Res. 29, 126-137. doi: 10.2307/1551843

Zarsky, J. D., Stibal, M., Hodson, A., Sattler, B., Schostag, M., Hansen, L. H., et al. (2013). Large cryoconite aggregates on a Svalbard glacier support a diverse microbial community including ammonia-oxidizing archaea. Environ. Res. Let. 8:35044. doi: 10.1088/1748-9326/8/3/035044

Zawierucha, K., Kolicka, M., Takeuchi, N., and Kaczmarek, Ł. (2015). What animals can live in cryoconite holes? A faunal review. J. Zool. 295, 159-169. doi: 10.1111/ jzo. 12195

Conflict of Interest Statement: The authors declare that the research was conducted in the absence of any commercial or financial relationships that could be construed as a potential conflict of interest.

Copyright (c) 2019 Takeuchi, Tanaka, Konno, Irvine-Fynn, Rassner and Edwards. This is an open-access article distributed under the terms of the Creative Commons Attribution License (CC BY). The use, distribution or reproduction in other forums is permitted, provided the original author(s) and the copyright owner(s) are credited and that the original publication in this journal is cited, in accordance with accepted academic practice. No use, distribution or reproduction is permitted which does not comply with these terms. 